\title{
Antimutagenic and Antibacterial Activity of $\beta$-Cyclodextrin Clathrates with Extensive Hydrolysates of Colostrum and Whey
}

\author{
Tatsiana M. Halavach ${ }^{1 * * \mathbb{D}}$, Ekaterina S. Savchuk ${ }^{1}{ }^{\mathbb{D}}$, Angelina S. Bobovich ${ }^{1(\mathbb{D})}$, \\ Natalia V. Dudchik ${ }^{2(\mathbb{D})}$, Vasili G. Tsygankow ${ }^{2(\mathbb{D})}$, Ekaterina I. Tarun ${ }^{3}{ }^{\mathbb{D}}$, Aleksei V. Yantsevich ${ }^{4}$, \\ Vladimir P. Kurchenko ${ }^{1}$ (D), Vladimir D. Kharitonov 5 (D), Vladimir A. Asafov 5 (D) \\ Belarusian State University, Nezavisimosti Av. 4, 220030 Minsk, Belarus \\ 2 RUE «Scientific Practical Centre of Hygiene», Akademicheskaya Str. 8, 20012 Minsk, Belarus \\ 3 International Sakharov Environmental Institute of Belarusian State University, Dolgobrodskaya Str. 23/1, 220070 Minsk, \\ Belarus \\ 4 Institute of Bioorganic Chemistry of the National Academy of Sciences of Belarus, Akademika V.F. Kuprevicha Str. 5/2, \\ 220141 Minsk, Belarus \\ 5 All-Russian Research Institute of Dairy Industry, Lusinovskaya Str. 35/7, 115093 Moscow, Russia \\ * Correspondence: halavachtn@gmail.com;
}

Scopus Author ID 57190978534

Received: 5.07.2020; Revised: 30.07.2020; Accepted: 31.07.2020; Published: 2.08.2020

\begin{abstract}
In this study, experimental samples of extensive enzymatic hydrolysates of bovine colostrum and whey, inclusion complexes of $\beta$-cyclodextrin with dairy peptides were derived. 1.6-fold increase in the degree of proteolysis was established for whey hydrolysate compared to cleaved first milk. A significant decline in the bitterness of peptide constituents of clathrates was recorded versus samples of initial extensive hydrolysates. The thermogravimetric analysis confirmed the formation of inclusion complexes of cyclic oligosaccharide with dairy peptides. The Ames test demonstrated comparable induced mutation rates for samples of hydrolysates and clathrates. Antimutagenic activity of the samples reached 23.9-28.3\% when tested on strain Salmonella typhimurium TA 98 and 19.4-21.8 \% on strain TA 100. According to the impedimetric method, the antibacterial potential of extensive colostrum hydrolysate exceeded the action of cleaved whey against Escherichia coli ATCC 8739 and Staphylococcus aureus ATCC 6538. Enhanced antibacterial activity was found for whey and colostrum peptide fractions included in clathrates with a cyclic oligosaccharide. $\beta$-cyclodextrin complexing preserved antimutagenic capacity, promoted antibacterial effect, and improved organoleptic properties of milk peptides. These advantages acquire maximum relevance during the clathrate upgrading of specialized nutrition formulas.
\end{abstract}

Keywords: Whey; Colostrum; Extensive hydrolysate; Peptide bitterness; $\beta$-Cyclodextrin clathrates with peptides; Thermogravimetry; Organoleptic properties; Antimutagenic action; Antibacterial effect.

(C) 2020 by the authors. This article is an open-access article distributed under the terms and conditions of the Creative Commons Attribution (CC BY) license (https://creativecommons.org/licenses/by/4.0/).

\section{Introduction}

Enzymatic hydrolysates of dairy proteins are potential sources of biologically active peptides with antioxidant, antimutagenic, hypotensive, antimicrobial, immunomodulatory, and other effects [1-4]. Proteolytic enzymes of microbial, animal, and plant origin with diverse mechanisms of catalytic action are used to produce hydrolysates with specified parameters (cleavage degree, molecular mass distribution of peptides, biological activities) [5-8]. 
Partial hydrolysates of proteins with a medium and profound degree of hydrolysis (extensive hydrolysates) are distinguished. Semi-hydrolyzed samples include peptides of various lengths (molecular mass, $\mathrm{mr}<10 \mathrm{kDa}$ ) and a minimum amount of free amino acids, whereas deep hydrolysates contain short-chain peptides ( $\mathrm{mr} 3-5 \mathrm{kDa}$ or less) [9-12]. An increase in proteolysis degree directly affects their allergenicity [13, 14].

Concentrates of dairy proteins are chosen as the optimal substrates for hydrolysis. A readily available proteinaceous feedstock is derived by processing whey - a by-product of cheese and casein manufacturing $[5,9,15]$. At the same time, colostrum (first milk) differs significantly from regular milk in nutritional value and composition of biologically active components. Colostrum is characterized by a high content of valuable whey proteins, immune factors, and natural antioxidants, allowing it to refer it to promising hydrolysate sources [1620].

It should be noted that extensive protein hydrolysates with low allergenic potential possess bitterness that limits their use as food components [5, 21]. The bitterness is mainly determined by the composition of amino acids and their polarity, as well as by peptide size, temperature, and active acidity of the medium. The major amino acids imparting bitter taste to peptides are phenylalanine, tryptophan, tyrosine, isoleucine, proline, and histidine [22, 23]. It is advisable to introduce new methods to preserve biologically active components and improve the organoleptic properties of hydrolysates.

Cyclodextrins (CD) are cyclic oligosaccharides consisting of $6(\alpha-C D), 7(\beta-C D)$, $8(\gamma-\mathrm{CD})$ and more glucopyranose residues linked by $\alpha-(1,4)$-bonds. Due to specific conical spatial structure, comprising a hydrophobic cavity, CDs display the ability to form inclusion complexes with various compounds [24-27]. The formation of $\alpha$ - and $\beta$-CD clathrates with phenylalanine, tryptophan, tyrosine, isoleucine, proline, and histidine was proved using NMR-techniques. Complexing process diminished sensation of bitterness in some amino acids [28-30], and soybean protein hydrolysate [22], so that $\alpha$ - and $\beta-C D$ were recommended as promising flavor modifiers of novel functional foodstuffs.

The previous studies [31-36] demonstrated decreased antigenic capacity of milk protein hydrolysates with middle decomposition rate and enhanced antiradical, antimicrobial, and antimutagenic activities of peptide fraction (over those of the native substrates). In addition, organoleptic and antioxidant properties of $\beta-C D$ clathrates with commercial whey hydrolysate were characterized [37].

Currently, the derived supramolecular complex (insulin/R8-carboxymethyl- $\beta$-CD) has been shown to significantly promote insulin permeability, achieving the best biological effect in tests on diabetic rats [38]. Results of the trials qualified R8-CM- $\beta-C D$ as an excellent carrier for the delivery of protein macromolecules. $\beta$-CD complexing raised proteolysis resistance of antimicrobial peptides ABP-CM4 [39] and nisin [40] and preserved their biological activities. The proposed approaches can be applied to obtain clathrates with antimicrobial peptides for the food industry.

In general, the formation of inclusion complexes with cyclodextrins subdues bitterness of peptides. However, so far, the effect of complexing on functional characteristics of dairy peptides has not been explored in detail. The relevance of research is determined by the need to optimize the technology for producing extensive hydrolysates of dairy proteins with desired physicochemical parameters and acceptable organoleptic properties, as well as confirmed biological action. 
Experimental findings on optimization of $\beta-\mathrm{CD}$ complexing with peptides, characterization of bioactive properties of clathrates lay the basis for the formulation of technology specifying the production of inclusion complexes with extensive dairy hydrolysates. Potential practical usage of extensive hydrolysates and clathrates may be related to the enrichment of specialized diets. The novelty of this research implies collecting new data describing biological activities of whey and colostrum extensive proteins hydrolysates, the impact of $\beta$-CD complexes on properties of dairy peptides. The effect is achieved by including amino acid residues of specific peptides into the hydrophobic cavity of cyclic oligosaccharide.

The aim of this study was to obtain extensive hydrolysates of whey and colostrum proteins and their inclusion complexes with $\beta-\mathrm{CD}$, to estimate antimutagenic activity and antimicrobial action of hydrolysates and clathrates.

\section{Materials and Methods}

\subsection{Production of hydrolysate/clathrate samples and their physical-chemical characterization.}

Whey protein concentrate (specifications BY 100377914.550-2008), dry defatted colostrum (All-Russian Research Institute of Dairy Industry, Moscow, Russia), serine protease (Alcalase ${ }^{\circledR}$ 2.4L, EC 3.4.21.62, derived from Bacillus licheniformis, enzyme activity $2.4 \mathrm{U} / \mathrm{g}$, Sigma, USA), $\beta$-CD manufactured by Roquette (France) were used in experimental work.

\subsubsection{Production of extensive hydrolysates of dairy proteins.}

$5 \%$ solutions of first milk and whey in phosphate buffer $(\mathrm{pH} 7.4)$ were prepared. The resulting solutions were centrifuged to remove insoluble particles at 10,000 rpm for $30 \mathrm{~min}$, and the supernatant was applied for hydrolysis. The enzymatic splitting reaction was carried out at enzyme/substrate ratio $5 \%$, temperature $50{ }^{\circ} \mathrm{C}$, and $\mathrm{pH}$ value 7.4 during $3 \mathrm{~h}$ with colostrum substrate and $2 \mathrm{~h}$ in case of whey. Spin-X UF Concentrator 20 filters (Corning, England) with sieving capacity $5 \mathrm{kDa}$ were chosen for hydrolysate fractionation. The samples were frozen at $-20{ }^{\circ} \mathrm{C}$ for subsequent analysis.

The content of total protein in the samples of colostrum and whey, their hydrolysates, and ultrafiltrates was estimated in compliance with ISO 8968-1:2014 [41], the concentration of solids was determined according to ISO 6731:2010 [42]. The amount of low molecular mass (LMM) fraction (\%) was computed as the ratio of protein amount in ultrafiltrate to protein content in the initial hydrolysate.

The share of hydrolysed protein fraction in the samples was calculated by the formula (1):

$$
\mathrm{DP}=\frac{\mathrm{N}_{\mathrm{UF}}-\mathrm{N}_{\mathrm{c}}}{\mathrm{N}-\mathrm{N}_{\mathrm{c}}} \times 100
$$

where DP - degree of proteolysis, \%; NUF - the amount of total protein in ultrafiltrate of the hydrolyzed sample, $\mathrm{mg} / \mathrm{ml} ; \mathrm{N}$ - the amount of total protein in a hydrolyzed sample, $\mathrm{mg} / \mathrm{ml} ; \mathrm{N}_{\mathrm{C}}$ - the amount of total protein in ultrafiltrate of the native sample (control), $\mathrm{mg} / \mathrm{ml}$. The research results were adduced as arithmetic means of 3 experiments.

The peptide profile of whey and colostrum samples was dissected by chromato-massspectrometry. Chromato-mass-spectrometric system Agilent 1290 (Agilent, USA)) with highresolution MS-detector Q-TOF 6550 in positive electrospray ionization $\left(\mathrm{ESI}^{+}\right)$mode was used to record mass spectra. The spectral detection range was 100-3200 m/z (mass to charge ratio). 
HPLC-analysis was conducted using liquid chromatograph Agilent 1290 with the Hypersil Gold column $(100 \times 2.1 \mathrm{~mm}, 1.9 \mu \mathrm{m}$, Agilent, USA $)$.

\subsubsection{Production of $\beta$-CD clathrates with dairy peptides.}

Solutions containing cyclic oligosaccharide and dairy hydrolysates in mass proportion 2:1 (calculated as solids) were prepared. The obtained solutions were incubated during $4 \mathrm{~h}$ at temperature $50{ }^{\circ} \mathrm{C}$ with continuous stirring $(200 \mathrm{rpm})$. Organoleptic properties of liquid samples were defined using the procedure described in [30]. When tasting, whey and colostrum hydrolysates served as the control. Experimental samples of hydrolysates and clathrates were freeze-dried at temperature $-53{ }^{\circ} \mathrm{C}$, pressure 0.1 atm during $48 \mathrm{~h}$ for successive analysis.

Thermal decomposition parameters of $\beta$-CD clathrates with dairy peptides were determined by thermogravimetric analysis (TGA) and differential scanning calorimetry (DSC) using TGA/DSCI instrument (Mettler Toledo, Switzerland). The sample amount was $20 \mathrm{mg}$, analysis resolution limit equaled $1 \mu \mathrm{g}$. TGA/DSC procedure was conducted in the range 30 $600{ }^{\circ} \mathrm{C}$; the rate of temperature rise attained $5{ }^{\circ} \mathrm{C} / \mathrm{min}$; the accuracy of temperature control was $\pm 2{ }^{\circ} \mathrm{C}$. The effective activation energy $\left(\mathrm{E}_{\mathrm{a}}\right)$ was assessed in accordance with the Broido method using TGA-curves [43]. Pure compounds (peptides and $\beta-\mathrm{CD}$ ) and their mixtures in mass ratio 2:1 served as the control samples.

\subsection{Estimation of antimutagenic activity.}

Antimutagenic activity of whey and colostrum peptide fractions and their clathrates with $\beta-C D$ was determined by the modified Ames test in accordance with [32, 44]. Salmonella typhimurium TA 98 and TA 100 strains were used as short-term indicators of antimutagenic action. Ethidium bromide and sodium azide $(10 \mu \mathrm{g}$ per plate) were introduced as direct mutagens for strains TA 98 and TA 100, respectively. The antimutagenic effect of hydrolysate and clathrate samples was examined in the concentration range $0.5-0.25-0.123-0.063-$ $0.03 \mathrm{mg}$ of protein per plate (in 3 replicates). Reduction of the mutation rate ( $\mathrm{Im}, \%)$ was computed by the formula (2):

$$
\mathrm{I}_{\mathrm{M}}=100-\frac{\mathrm{N}_{1}}{\mathrm{~N}_{2}} \times 100
$$

where $\mathrm{N}_{1}$ - the number of revertants in the experiment, $\mathrm{N}_{2}$ - the number of revertants in the positive control. The statistical significance of the results was verified by Dunnett's multiple comparison test.

\subsection{Investigation of antibacterial action.}

Antibacterial activity of extensive colostrum/whey hydrolysates and their clathrates with cyclic oligosaccharide was evaluated by the impedimetric method described in [45-47]. The final concentration of the solids in the tested samples was $1.0 \mathrm{mg} / \mathrm{ml}$. Bacterial strains Escherichia coli ATCC 8739 (E. coli ATCC 8739) and Staphylococcus aureus ATCC 6538 (S. aureus ATCC 6538) were provided by All-Russian collection of industrial microorganisms as the test cultures. The studies were carried out using BacTrac 4300 microbiological impedance analyzer (SY-LAB, Austria). Inhibition index I (\%) calculated by the formula (3) was taken as a quantitative criterion for assessing antibacterial action:

$$
\mathrm{I}=\frac{\mathrm{IDT}_{2}-\mathrm{IDT}_{1}}{\mathrm{IDT}_{2}} \times 100
$$


where $\mathrm{IDT}_{1}$ - the time of growth detection of the test culture in control, h; IDT 2 - the time of growth detection of the test culture in the experiment, h. I index over zero marks denotes the expression of antimicrobial activity by the tested compound. I values under $15 \%$ signify a weak antibacterial effect on the test cultures, I ranging from 15 to $50 \%$ means a moderate antibacterial action, I exceeding $50 \%$ indicate strong antibacterial impact. The research results were presented as the arithmetic means $(n=3)$.

\section{Results and Discussion}

3.1. Physical-chemical and organoleptic properties of extensive dairy hydrolysates/derived clathrates.

The peptide composition of extensive dairy hydrolysates was analyzed based on total protein content in the respective ultrafiltrates and chromato-mass-spectrometry data. It was found that proteolysis degree in samples of extensive whey and first milk hydrolysates reached 37.2 and $22.7 \%$, while the percentage of a low molecular mass fraction $(\mathrm{mr} \leq 5 \mathrm{kDa})$ equaled 39.0 and $30.8 \%$, respectively. The obtained results evidence that the share of split protein component in whey protein hydrolysate was enlarged over that in hydrolyzed colostrum by 1.6 and 1.3 times in terms of proteolysis degree and content of low molecular mass fraction, respectively. The comparative characterization of hydrolysates and clathrates is presented in Table 1.

Table 1. Comparative analysis of the physical-chemical and organoleptic properties of extensive dairy hydrolysates and their clathrates with $\beta-C D$.

\begin{tabular}{l|c|c|c|c} 
Sample name & $\begin{array}{l}\text { LMM fraction } \\
\text { content/degree of } \\
\text { proteolysis, \% }\end{array}$ & $\begin{array}{l}\text { Characteristics of peptide } \\
\text { fraction }\end{array}$ & $\begin{array}{l}\text { Relative } \\
\text { bitterness, \% }\end{array}$ & $\begin{array}{l}\text { Activation } \\
\text { energy } \\
\text { kJ/mol }\end{array}$ \\
\hline Whey hydrolysate $(\mathrm{WH})$ & $39.0 / 37.2$ & $\begin{array}{c}\text { peptides with mr } \approx 680 \mathrm{Da} \\
\text { predominated }\end{array}$ & 80 & 76 \\
\hline Clathrate $(\mathrm{WH}-\beta-\mathrm{CD})$ & - & - & 50 & 105 \\
\hline Colostrum hydrolysate $(\mathrm{CH})$ & $30.8 / 22.7$ & $\begin{array}{c}\text { peptides with mr 560-650 Da } \\
\text { preponderated }\end{array}$ & 100 & 66 \\
\hline Clathrate $(\mathrm{CH}-\beta-\mathrm{CD})$ & - & - & 50 & 107
\end{tabular}

Chromato-mass-spectrometry of hydrolyzed whey revealed domination of monocharged ions with $\mathrm{m} / \mathrm{z}$ values $680-900$, corresponding to peptide size $680-900 \mathrm{Da}$, or peptide length of 6-8 amino acid residues. Mass spectrometry of cleaved colostrum detected the maximum signal at $\mathrm{m} / \mathrm{z} 560-650$, matching the equivalent peptide size, or peptide length of 56 amino acid residues. Thus, colostrum treated with highly active protease (alcalase) was distinguished by the presence of peptides with inferior molecular mass.

In general, alcalase-cleaved whey samples differed by a higher proteolysis degree and a larger amount of peptide fraction from hydrolyzed first milk samples. However, according to mass spectrometry, extensive colostrum hydrolysate contained peptides with a lower molecular mass. This is due to the more effective enzymatic splitting of colostrum casein as compared with whey proteins.

At the next stage, $\beta$-CD inclusion complexes with whey and colostrum peptides were derived, and their organoleptic properties were evaluated. Samples of extensive whey and colostrum hydrolysates displayed pronounced bitter taste. The level of bitterness of colostrum hydrolysate was rated as $100 \%$ on 10-point scale, while the sample of cleaved whey proteins scored 8 points. Incubation of peptides with a cyclic oligosaccharide mildened the taste to 
moderately bitter ( 5 points) when compared with control samples of hydrolysates. Thus, $\beta-C D$ complexing considerably upgraded flavor of the resulting clathrates.

In order to confirm the formation of $\beta$-CD complexes with whey/colostrum peptides, TGA/DSC method was applied. The curve of sample mass loss (thermogravimetry, TG/TG) and the curve correlating sample mass alteration with the temperature of the system (differential thermogravimetry, DTG/DTG) were subjected to comparative analysis. The dominant peak of $\beta$-CD thermal decomposition, albeit shifted and altered in shape, was shown to be retained in the clathrate samples. Noteworthy, that decomposition peaks typical for simple peptide mixtures were virtually not recorded, providing thereby indirect evidence of complexing process. $E_{a}$ measurements support the assumption that peptides derived from whey and colostrum tend to be more stable upon mixing and complexing with $\beta$-CD.

\subsection{Antimutagenic effect of colostrum and whey peptides and their clathrates.}

Antimutagenic action of peptide fractions $(\mathrm{mr} \leq 5 \mathrm{kDa})$ of hydrolyzed whey and colostrum was studied. As a rule, the antimutagenic potential of dairy peptides is assessed in the Ames test based on the frequency of reverse mutations to histidine prototrophy in Salmonella typhimurium strains [44, 48-51]. When choosing the concentration range of the samples, potential antibacterial effect, and the previous results evaluating the antimutagenic activity of colostrum enzymatic hydrolysates were considered [33, 34, 36].

Hydrolysate and clathrate samples in concentration range $0.03-0.5 \mathrm{mg}$ protein per plate did not demonstrate a bacteriostatic or bactericidal effect in relation to test models S. typhimurium TA 98 and TA 100, which could lead to false-positive results. The strain response to mutagens (positive control) varied within standard fluctuations. Differences between the revertants number in the experiment were statistically negligible relative to the negative control $(\mathrm{p}<0.05)$

A statistically significant decline in induced mutation rate was recorded for samples of hydrolysates and clathrates. The revealed distinctions in revertants number for control and test samples were statistically authentic in the studied concentrations range. Nevertheless, ultrafiltrates of native whey and colostrum, and cyclic oligosaccharide sample lacked antimutagenic activity.

Table 2. Statistical evaluation of the antimutagenic activity of whey protein hydrolysate $(\mathrm{mr} \leq 5 \mathrm{kDa})$.

\begin{tabular}{l|c|c}
\multirow{2}{*}{ Sample amount, mg solids/protein per plate } & \multicolumn{2}{|c}{ Decrease of mutation rate, \% } \\
\cline { 2 - 3 } & S. typhimurium TA 100 & S. typhimurium TA 100 \\
\hline $0.85 / 0.50$ & 25.9 & 20.3 \\
\hline $0.43 / 0.25$ & 23.1 & 18.8 \\
\hline $0.21 / 0.13$ & 20.3 & 16.4 \\
\hline $0.10 / 0.06$ & 17.3 & 14.2 \\
\hline $0.05 / 0.03$ & 14.1 & 12.1 \\
\hline 0 & - & -
\end{tabular}

Table 3. Statistical evaluation of the antimutagenic activity of colostrum protein hydrolysate $(\mathrm{mr} \leq 5 \mathrm{kDa})$.

\begin{tabular}{l|l|l}
\multirow{2}{*}{ Sample amount, mg solids/protein per plate } & Decrease of mutation rate, \% & \\
\cline { 2 - 3 } & S. typhimurium TA 100 & S. typhimurium TA 100 \\
\hline $1.17 / 0.50$ & 23.9 & 19.4 \\
\hline $0.59 / 0.25$ & 20.0 & 17.1 \\
\hline $0.29 / 0.13$ & 16.4 & 15.4 \\
\hline $0.15 / 0.06$ & 13.2 & 15.0 \\
\hline $0.07 / 0.03$ & 9.2 & 8.6 \\
\hline 0 & - & -
\end{tabular}


According to the results presented in Tables 2-5, the decrease in induced mutation rate when samples were added at maximum concentration $0.5 \mathrm{mg}$ protein per plate reached 23.9$28.3 \%$ for strain S. typhimurium TA 98 and 19.4-21.8\% in the experiment with TA 100. It was found that hydrolysate and clathrate samples in the examined concentration range showed comparable antimutagenic effects on S. typhimurium TA 100 strain.

Table 4. Statistical evaluation of the antimutagenic activity of $\beta$-cyclodextrin clathrate with whey peptides (whey protein hydrolysate, $\mathrm{mr} \leq 5 \mathrm{kDa}$ ).

\begin{tabular}{l|c|c}
\multirow{2}{*}{ Sample amount, mg solids/protein per plate } & \multicolumn{2}{|c}{ Decrease of mutation rate, \% } \\
\cline { 2 - 3 } & S. typhimurium TA 100 & S. typhimurium TA 100 \\
\hline $2.75 / 0.50$ & 28.3 & 21.8 \\
\hline $1.37 / 0.25$ & 24.2 & 20.0 \\
\hline $0.69 / 0.13$ & 20.3 & 17.9 \\
\hline $0.34 / 0.06$ & 16.4 & 15.9 \\
\hline $0.17 / 0.03$ & 14.1 & 12.5 \\
\hline 0 & - & -
\end{tabular}

Table 5. Statistical evaluation of the antimutagenic activity of $\beta$-cyclodextrin clathrate with colostrum peptides (colostrum protein hydrolysate, $\mathrm{mr} \leq 5 \mathrm{kDa}$ ).

\begin{tabular}{l|c|c}
\multirow{2}{*}{ Sample amount, mg solids/protein per plate } & \multicolumn{2}{|c}{ Decrease of mutation rate, \% } \\
\cline { 2 - 3 } & S. typhimurium TA 100 & S. typhimurium TA 100 \\
\hline $3.51 / 0.50$ & 25.2 & 21.2 \\
\hline $1.75 / 0.25$ & 21.0 & 18.6 \\
\hline $0.88 / 0.13$ & 18.3 & 17.0 \\
\hline $0.44 / 0.06$ & 14.9 & 15.1 \\
\hline $0.22 / 0.03$ & 10.0 & 13.8 \\
\hline 0 & - & -
\end{tabular}

It is of special interest that a more dramatic increase in antimutagenic activity was observed in experiments with S. typhimurium TA 98 following supply of $0.03-0.50 \mathrm{mg} / \mathrm{ml}$ of whey hydrolysate into the test system when compared with colostrum hydrolysate sample (14.1-25.9\% versus 9.2-23.9\%). A similar effect was established for clathrates: the antimutagenic potential of $\beta-\mathrm{CD}$ inclusion complex with whey peptides $(14.1-28.3 \%)$ exceeded the values of its analog with colostrum peptides (10.0-25.2\%). It should be noted that samples of dairy protein hydrolysates and corresponding clathrates were characterized by the comparable level of induced mutation activity. It may be deduced, therefore, that the antimutagenic capacity of whey/colostrum peptides was not affected by $\beta$-CD complexing.

Table 6. Statistical evaluation of the antimutagenic activity of fermented colostrum ultrafiltrate $(\mathrm{mr} \leq$ $10 \mathrm{kDa})[52]$.

\begin{tabular}{l|c|c}
\multirow{2}{*}{ Sample amount, mg solids/protein per plate } & \multicolumn{2}{|c}{ Decrease of mutation rate, \% } \\
\cline { 2 - 3 } & S. typhimurium TA 100 & S. typhimurium TA 100 \\
\hline $1.70 / 0.49$ & 15.3 & 11.1 \\
\hline $0.85 / 0.25$ & 13.3 & 9.0 \\
\hline $0.43 / 0.12$ & 9.5 & 4.6 \\
\hline $0.21 / 0.06$ & 0 & 0 \\
\hline $0.11 / 0.03$ & 0 & 0 \\
\hline 0 & - & -
\end{tabular}

According to the previous studies [52], induced mutation level of fermented colostrum (peptide fraction with $\mathrm{mr} \leq 10 \mathrm{kDa}$ ) in the same concentration range was $9.5-15.3 \%$ for strain S. typhimurium TA 98 and 4.6-11.1\% for strain TA 100, as reflected in Table 6. The increased amount of peptide fraction promoted the enhanced antimutagenic activity of the fermented colostrum in comparison with the initial defatted sample. 
Furthermore, analysis of peptide fraction with $\mathrm{mr} \leq 10 \mathrm{kDa}$ resulting from hydrolysis with alcalase and ultrafiltration stated 10.0-21.2 \% reduction of mutation rate in a test system with S. typhimurium TA 98 (protein concentration $0.03-0.54 \mathrm{mg}$ per plate) $[33,34,36]$, as illustrated by Table 7 . Consequently, the antimutagenic activity of the sample with an average degree of hydrolysis was considerably lower than that of extensive whey hydrolysate containing fraction with $\mathrm{mr} \leq 5 \mathrm{kDa}$. Relatively high antimutagenic effect of deep hydrolysate may be accounted for by the presence of low molecular mass peptide components.

The reports of M.B.E. Turbay et al. (2012) [48] and B.N.P. Sah et al. $(2014,2015)[49,51]$, our experimental findings $[33,34,36,52]$ and the present study vividly demonstrated the elevated antimutagenic potential of fermented and enzymatically hydrolyzed dairy proteins.

Table 7. Statistical evaluation of the antimutagenic activity of hydrolyzed colostrum ultrafiltrate $(\mathrm{mr} \leq 10 \mathrm{kDa})[36]$.

\begin{tabular}{l|c|c}
\multirow{2}{*}{ Sample amount, mg solids/protein per plate } & \multicolumn{2}{|c}{ Decrease of mutation rate, \% } \\
\cline { 2 - 3 } & S. typhimurium TA 100 & S. typhimurium TA 100 \\
\hline $10.88 / 8.70$ & 29.6 & 32.4 \\
\hline $2.72 / 2.18$ & 23.6 & 29.1 \\
\hline $0.68 / 0.54$ & 21.2 & 20.0 \\
\hline $0.17 / 0.14$ & 15.6 & 18.0 \\
\hline $0.04 / 0.03$ & 10.0 & 12.5 \\
\hline 0 & - & -
\end{tabular}

3.3. Antibacterial activity of cyclodextrin complexes with extensive dairy hydrolysates.

Subsequently, antibacterial properties of extensive colostrum and whey hydrolysates (peptide fractions with $\mathrm{mr} \leq 5 \mathrm{kDa}$ ) and their clathrates with $\beta$-CD were studied in relation to the Gram-negative test strain E. coli ATCC 8739 and Gram-positive test strain S. aureus ATCC 6538.

Antibacterial peptides are known to inhibit growth or cause the death of microbial cells. Amino acid composition, amphipathicity, cationic charge, and size of peptides determine the ability to bind with anionic cell walls and to integrate into membrane bilayers of microorganisms [1, 53-55].

Growth retardation of test cultures was assessed after supply into the nutrient medium of ultrafiltrates of native and hydrolyzed whey and colostrum, corresponding clathrates, and a control sample of $\beta$-CD. Antimicrobial activity was not revealed in experiments with ultrafiltrates of native milk proteins and cyclic oligosaccharide. Alongside this, an increase in IDT growth detection time parameter was established for test strains E. coli ATCC 8739 and S. aureus ATCC 6538 in the medium with extensive dairy hydrolysates and their clathrates as compared with IDT in control.

The results evaluating the antibacterial activity of colostrum/whey hydrolysates and their clathrates in relation to testing strains are shown in Table 8. In particular, the growth delay of $E$. coli ATCC 8739 was 1.0/3.6 h when extensive whey/colostrum hydrolysates were added to the nutrient medium, indicating a moderately expressed effect (I from 15 to $50 \%$ ).

The similar antibacterial action was displayed by $\beta-\mathrm{CD}$ clathrate with whey peptides causing $1.5 \mathrm{~h}$ growth inhibition of Gram-negative microorganisms upon introduction into the culture medium. Of special note was a strong antibacterial effect of $\beta$-CD clathrate with colostrum peptides $(68.1 \%)$, inducing growth cessation of E. coli ATCC 8739 for $10.9 \mathrm{~h}$. 
Table 8. The level of antibacterial activity of extensive dairy hydrolysates (peptide fractions, $\mathrm{mr} \leq 5 \mathrm{kDa}$ ) and their clathrates in relation to testing strains.

\begin{tabular}{|c|c|c|c|}
\hline \multirow[b]{2}{*}{ Sample description } & \multirow{2}{*}{$\begin{array}{l}\text { Sample amount, } \\
\text { mg solids/protein per } \\
\text { plate }\end{array}$} & \multicolumn{2}{|c|}{ Percentage of inhibition index (I) toward test strains } \\
\hline & & E. coli ATCC 8739 & S. aureus ATCC 6538 \\
\hline Whey hydrolysate (WH) & $1.0 / 0.59$ & $16.4 \%$ (moderate) & $7.2 \%$ (weak) \\
\hline Colostrum hydrolysate $(\mathrm{CH})$ & $1.0 / 0.43$ & $41.4 \%$ (moderate) & $13.5 \%$ (weak) \\
\hline Complex $\beta$-CD+WH & $1.0 / 0.18$ & $22.7 \%$ (moderate) & $8.6 \%$ (weak) \\
\hline Complex $\beta-\mathrm{CD}+\mathrm{CH}$ & $1.0 / 0.14$ & $68.1 \%$ (strong) & $17.9 \%$ (moderate) \\
\hline
\end{tabular}

In relation to $S$. aureus ATCC 6538, the impact of extensive hydrolysates and $\beta$-CD clathrate with whey peptides was relatively weak (7.2-13.5\% of growth inhibition), resulting in IDT rise of $0.5-1.0 \mathrm{~h}$. On the contrary, growth retardation of $1.4 \mathrm{~h}$ and the augmented antibacterial activity up to $17.9 \%$ was manifested by $\beta$-CD clathrate with colostrum peptides.

In general, colostrum and whey protein hydrolysates proved more active against Gramnegative test strain E. coli ATCC 8739 rather than Gram-positive strain S. aureus ATCC 6538. Antibacterial properties of colostrum peptide fraction were more pronounced than those of whey peptides. Cyclic oligosaccharide complexing with whey and colostrum peptides promoted antibacterial potential. The maximum growth delay of E. coli ATCC 8739 and S. aureus ATCC 6538 was established when $\beta$-CD clathrate with colostrum peptides was added to the culture medium.

According to the previous studies [35, 36, 52], the antibacterial action of hydrolyzed colostrum was greater in comparison with fermented variant and digested whey, as reflected by Table 9. In addition, peptide fractions of cleaved whey and colostrum with $\mathrm{mr} \leq 10 \mathrm{kDa}$ displayed a more potent antibacterial effect than extensive hydrolysates with smaller peptides $(\mathrm{mr} \leq 5 \mathrm{kDa})$.

Table 9. The level of antibacterial activity of hydrolyzed and fermented colostrum, cleaved whey (peptide fractions, $m r \leq 10 \mathrm{kDa}$ ) in relation to testing strains [35, 36, 52].

\begin{tabular}{l|l|l|l}
\multirow{2}{*}{ Sample description } & \multirow{2}{*}{$\begin{array}{l}\text { Sample amount, } \\
\text { mg solids/protein per plate }\end{array}$} & \multicolumn{2}{|l}{ Percentage of inhibition index (I) toward test strains } \\
\hline Fermented colostrum & $1.0 / 0.29$ & $38 \%$ (moderate) & $6.2 \%$ (weak) \\
\hline Hydrolysed colostrum & $1.27 / 0.30$ & $57 \%$ (strong) & $9 \%$ (weak) \\
\hline Hydrolysed whey & $0.38 / 0.30$ & $34 \%$ (moderate) & $13 \%$ (weak)
\end{tabular}

Distinctions in the level of antibacterial action may be accounted for by milk proteolysis with various enzymes (alcalase and proteolytic system of Lactobacillus acidophilus), the composition of the protein component of colostrum and whey, governing the generation of specific peptides with antimicrobial activity. Moreover, post-hydrolytic ultrafiltration of samples also contributes to the profile of resulting peptide fractions.

Analysis of available survey data [53-56] has revealed that peptides with antimicrobial properties identified to date originated from cleavage of milk proteins by enzymes of the gastrointestinal tract (pepsin, chymosin, trypsin, and chymotrypsin) and from fermentation by probiotic lactic acid bacteria (Lb. rhamnosus, Lb helveticus, Lb. delbrueckii ssp. bulgaricus). The novelty of this research consists of a comprehensive comparative investigation of antimutagenic and antibacterial effects of alcalase-derived extensive hydrolysates of whey and colostrum proteins and their clathrates with $\beta-\mathrm{CD}$.

\section{Conclusions}

Comparative examination of the peptide composition of hydrolyzed whey and colostrum was conducted. In whey hydrolysate, the share of split protein component rose by 
1.6 and 1.3 times calculated as a degree of proteolysis and content of low molecular mass fraction, respectively. However, peptides with a lower molecular mass were detected by chromato-mass-spectrometry in extensive colostrum hydrolysate. These findings may be due to the more effective splitting of first milk casein into short-chain peptides as compared with globular whey proteins relatively resistant to alcalase proteolysis.

Experimental samples of $\beta$-cyclodextrin clathrates with peptides of whey and colostrum were produced, and their organoleptic properties were evaluated. A considerable decrease of peptide bitterness in the inclusion complexes was established versus samples of extensive hydrolysates. The thermogravimetric analysis confirmed the formation of $\beta$-cyclodextrin clathrates with whey and colostrum peptides.

In the Ames test, a statistically significant decline in induced mutation rate was noted for hydrolysate and clathrate samples. They showed a comparable level of antimutagenic activity. Reduction in induced mutation rate when samples were introduced at maximum concentration $0.5 \mathrm{mg}$ protein per plate reached $23.9-28.3 \%$ in the test system with S. typhimurium TA 98 and $19.4-21.8 \%$ in the case of S.typhimurium TA 100 . The antimutagenic effect of whey/colostrum peptides remained at the same level after complexing with a cyclic oligosaccharide.

According to the impedimetric method, low molecular mass fractions of first milk and whey were more active against Gram-negative test strain E. coli ATCC 8739 than Grampositive strain S. aureus ATCC 6538. Experimental results proved superior antibacterial activity of hydrolyzed colostrum over cleaved whey. $\beta$-cyclodextrin complexing ensured enhanced antibacterial action of bound peptide fractions of whey and colostrum. The maximum growth retardation of E. coli ATCC 8739 and S. aureus ATCC 6538 (inhibition degree $68.1 \%$ and $17.9 \%$, respectively) was observed upon the supply of $\beta$-cyclodextrin clathrate with colostrum peptides into the culture medium.

Application prospects of dairy peptides included in clathrates with $\beta$-cyclodextrin appear promising as ingredients of specialized food formulas (infant, sports, dietetic nutrition).

\section{Funding}

This research received no external funding.

\section{Acknowledgments}

This research has no acknowledgment.

\section{Conflicts of Interest}

The authors declare no conflict of interest.

\section{References}

1. Daliri, E.; Oh, D.; Lee, B. Bioactive peptides. Foods 2017, 6, 32, https://doi.org/10.3390/foods6050032.

2. Sánchez, A.; Vázquez, A. Bioactive peptides: a review. Food Quality and Safety 2017, 1, 29-46, https://doi.org/10.1093/fqsafe/fyx006.

3. FitzGerald, R.J.; Cermeño, M.; Khalesi, M.; Kleekayai, T.; Amigo-Benavent, M. Application of in silico approaches for the generation of milk protein-derived bioactive peptides. Journal of Functional Foods 2019, 103636, https://doi.org/10.1016/j.jff.2019.103636.

4. Moughan, P.J. Milk proteins: a rich source of bioactives for developing functional foods. In Milk Proteins: From Expression to Food; 3rd ed.; Boland, M., Singh, H., Eds.; Academic Press: Cambridge, United States, 2020; 17, pp. 633-649. https://doi.org/10.1016/B978-0-12-815251-5.00017-7. 
5. Clemente, A. Enzymatic protein hydrolysates in human nutrition. Trends in Food Science and Technology 2000, 11, 254-262, https://doi.org/10.1016/S0924-2244(01)00007-3.

6. Aluko, R.E. Food protein-derived peptides: production, isolation, and purification. Woodhead Publishing Series in Food Science, Technology and Nutrition: Proteins in Food Processing 2018, 389-412, https://doi.org/10.1016/B978-0-08-100722-8.00016-4.

7. Raikos, V.; Dassios, T. Health-promoting properties of bioactive peptides derived from milk proteins in infant food: a review. Dairy Science and Technology 2013, 94, 91-101, https://doi.org/10.1007/s13594-0130152-3.

8. Liu, L.; Li, S.; Zheng, J.; Bu, T.; He, G.; Wu, J. Safety considerations on food protein-derived bioactive peptides. Trends in Food Science \& Technology 2020, 96, 199-207, https://doi.org/10.1016/j.tifs.2019.12.022.

9. Hernández-Ledesma, B.; García-Nebot, M.J.; Fernández-Tomé, S.; Amigo, L.; Recio, I. Dairy protein hydrolysates: peptides for health benefits. International Dairy Journal 2014, 38, 82-100, https://doi.org/10.1016/j.idairyj.2013.11.004.

10. Halavach, T.M.; Kurchenko, V.P. Milk protein hydrolysis with enzyme preparation and proteolytic systems of lactic acid bacteria. Proceedings of the Belarusian State University 2012, 7, 107-127. (In Russian).

11. Aase Kristoffersen, K.; Kristian Afseth, N.; Böcker, U.; Lindberg, D.; de Vogel-van den Bosch, H.; Linnéa Ruud, M.; Gizachew Wubshet, S. Average molecular weight, degree of hydrolysis and dry-film FTIR fingerprint of milk protein hydrolysates: intercorrelation and application in process monitoring. Food Chemistry 2019, 125800, https://doi.org/10.1016/j.foodchem.2019.125800.

12. Mann, B.; Athira, S.; Sharma, R.; Kumar, R.; Sarkar, P. Bioactive peptides from whey proteins. In Whey Proteins: From Milk to Medicine; 1st ed.; Deeth, Hilton C., Bansal, Nidhi, Eds.; Academic Press: Cambridge, United States, 2019; 14, pp. 519-547. https://doi.org/10.1016/B978-0-12-812124-5.00015-1.

13. Dhesi, A.; Ashton, G.; Raptaki, M.; Makwana, N. Cow's milk protein allergy. Paediatrics and Child Health 2020, 30, 255-260, https://doi.org/10.1016/j.paed.2020.04.003.

14. Nutten, S.; Schuh, S.; Dutter, T.; Heine, R.G.; Kuslys, M. Design, quality, safety and efficacy of extensively hydrolyzed formula for management of cow's milk protein allergy: what are the challenges? Advances in Food and Nutrition Research 2020, 93, 147-204, https://doi.org/10.1016/bs.afnr.2020.04.004.

15. Poppitt, S.D. Milk proteins and human health. In Milk Proteins: From Expression to Food; 3rd ed.; Boland, M., Singh, H., Eds.; Academic Press: Cambridge, United States, 2020; 18, pp. 651-669, https://doi.org/10.1016/B978-0-12-815251-5.00018-9.

16. Sacerdote, P.; Mussano, F.; Franchi, S.; Panerai, A.E.; Bussolati, G.; Carossa, S.; Bartorelli, A.; Bussolati, B. Biological components in a standardized derivative of bovine colostrum. Journal of Dairy Science 2013, 96, 1745-1754, https://doi.org/10.3168/jds.2012-5928.

17. Bagwe, S.; Tharappel, L.J.P.; Kaur, G.; Buttar, H.S. Bovine colostrum: an emerging nutraceutical. Journal of Complementary and Integrative Medicine 2015, 12, 175-185, https://doi.org/10.1515/jcim-2014-0039.

18. Mcgrath, B.A.; Fox, P.F.; Mcsweeney, P.L.H.; Kelly, A.L. Composition and properties of bovine colostrum: a review. Dairy Science \& Technology 2015, 96, 133-158, https://doi.org/10.1007/s13594-015-0258-x.

19. Dzik, S.; Miciński, B.; Aitzhanova, I.; Miciński, J.; Pogorzelska, J.; Beisenov, A.; Kowalski, I.M. Properties of bovine colostrum and the possibilities of use. Polish Annals of Medicine 2017, 24, 295-299, https://doi.org/10.1016/j.poamed.2017.03.004.

20. Baumrucker, C.R.; Macrina, A.L. Hormones and regulatory factors in bovine milk. Reference Module in Food Science 2020, https://doi.org/10.1016/B978-0-12-818766-1.00010-6.

21. Raksakulthai, R.; Haard, N.F. Exopeptidases and their application to reduce bitterness in food: a review. Critical Reviews in Food Science and Nutrition 2003, 43, 401-445, https://doi.org/10.1080/10408690390826572.

22. Cho, M.J.; Unklesbay, N.; Hsieh, F.; Clarke, A.D. Hydrophobicity of bitter peptides from soy protein hydrolysates. Journal of Agricultural and Food Chemistry 2004, 52, 5895-5901, https://doi.org/10.1021/jf0495035.

23. Saha, B.C.; Hayashi, K. Debittering of protein hydrolyzates. Biotechnology Advances 2001, 19, 355-370, https://doi.org/10.1016/S0734-9750(01)00070-2.

24. Szente, L.; Szejtli, J. Cyclodextrins as food ingredients. Trends in Food Science and Technology 2004, 15, 137-142, https://doi.org/10.1016/j.tifs.2003.09.019.

25. Del Valle, E.M.M. Cyclodextrins and their uses: a review. Process Biochemistry 2004, 39, 1033-1046, https://doi.org/10.1016/S0032-9592(03)00258-9.

26. Sharma, N.; Baldi, A. Exploring versatile applications of cyclodextrins: an overview. Drug Delivery 2016, 23, 729-747, https://doi.org/10.3109/10717544.2014.938839.

27. Bissessur, R. Nanomaterials applications. In Polymer Science and Nanotechnology: Fundamentals and Applications; Narain, R., Ed.; Academic Press: Cambridge, United States, 2020; 18, pp. 435-453, https://doi.org/10.1016/B978-0-12-816806-6.00018-2.

28. Nishijo, J.; Tsuchitani, M. Interaction of L-tryptophan with $\alpha$-cyclodextrin: studies with calorimetry and proton nuclear magnetic resonance spectroscopy. Journal of Pharmaceutical Sciences 2001, 90, 134-140, https://doi.org/10.1002/1520-6017(200102)90:2<134::AID-JPS4>3.0.CO;2-T. 
29. Linde, G.A.; Junior, A.L.; Faria, E.V. de; Colauto, N.B.; Moraes, F.F. de; Zanin, G.M. Taste modification of amino acids and protein hydrolysate by $\alpha$-cyclodextrin. Food Research International 2009, 42, 814-818, https://doi.org/10.1016/j.foodres.2009.03.016.

30. Linde, G.A.; Junior, A.L.; Faria, E.V. de; Colauto, N.B.; Moraes, F.F. de; Zanin, G.M. The use of 2D NMR to study $\beta$-cyclodextrin complexation and debittering of amino acids and peptides. Food Research International 2010, 43, 187-192, https://doi.org/10.1016/j.foodres.2009.09.025.

31. Halavach, T.N.; Kurchenko, V.P.; Zhygankov, V.G.; Evdokimov, I.A. Determination of physicochemical, immunochemical and antioxidant properties, toxicological and hygienic assessment of whey protein concentrate and its hydrolysate. Foods and Raw Materials 2015, 3, 105-114, http://doi.org/10.12737/13127.

32. Golovach, T.N.; Dudchik, N.V.; Veremeenko, E.G.; Tsygankou, V.G.; Bondaruk, A.M.; Filonyuk, V.A.; Shevlyakov, V.V.; Ushkov, A.A.; Sobol, Yu.A.; Erm, G.I.; Kurchenko, V.P. Evaluation of antimutagenic and antifungal properties, parameters of acute toxicity and sensitizing activity of enzymatic whey protein hydrolysate. Foods and Raw Materials 2016, 4, 38-47, http://doi.org/10.21179/2308-4057-2016-2-38-47.

33. Halavach, T.M.; Tarun, E.I.; Dudchik, N.V.; Romanovich, R.V.; Bubra, I.A.; Kurchenko, V.P. Antiradical activity, antimutagenic and antigenic properties of enzymatic bovine colostrum hydrolysates. Journal of the Belarusian State University (Biology) 2018, 1, 50-59. (In Russian).

34. Halavach, T.M.; Tarun, E.I.; Dudchik, N.V.; Romanovich, R.V.; Bubra, I.A.; Kurchenko, V.P. Description of biologically active protein hydrolysates of whey and colostrum. Proceedings of the National Academy of Sciences of Belarus (Biological series) 2018, 63, 409-418, https://doi.org/10.29235/1029-8940-2018-63-4409-418. (In Russian).

35. Halavach, T.M.; Dudchik, N.V; Bubra, I.A.; Kurchenko, V.P. Antimicrobial activity of peptides from colostrum and whey. News of Biomedical Sciences 2018, 17, 50-55. (In Russian).

36. Halavach, T.M.; Dudchik, N.V.; Tarun, E.I.; Zhygankov, V.G.; Kurchenko, V.P.; Romanovich, R.V.; Khartitonov, V.D.; Asafov, V.A. Biologically active properties of hydrolysed and fermented milk proteins. The Journal of Microbiology, Biotechnology and Food Sciences 2020, 9, 714-720, https://doi.org/10.15414/jmbfs.2020.9.4.714-720.

37. Halavach, T.M.; Tarun, E.I.; Zhygankov, V.G., Butina, A.D.; Kurchenko, V.P. Inclusion complexes of cyclodextrin with whey peptides: characteristic of antioxidant activity. Journal of the Belarusian State University (Biology) 2018, 3, 3-13. (In Russian).

38. Yang, L.; Li, M.; Sun, Y.; Zhang, L. A cell-penetrating peptide conjugated carboxymethyl- $\beta$-cyclodextrin to improve intestinal absorption of insulin. International. Journal of Biological Macromolecules 2018, 111, 685-695, https://doi.org/10.1016/j.ijbiomac.2018.01.077.

39. Li, J.F.; Zhang, J.X.; Wang, Z.G.; Yao, Y.J.; Han, X.; Zhao, Y.L.; Liu, J.P.; Zhang, S.Q. Identification of a cyclodextrin inclusion complex of antimicrobial peptide CM4 and its antimicrobial activity. Food Chemistry 2017, 221, 296-301, https://doi.org/10.1016/j.foodchem.2016.10.040.

40. Li, J.; Pan, D.; Yi, J.; Hao, L.; Kang, Q.; Liu, X.; Lu, L.; Lu, J. Protective effect of $\beta$-cyclodextrin on stability of nisin and corresponding interactions involved. Carbohydrate Polymers 2019, 223, https://doi.org/10.1016/j.carbpol.2019.115115.

41. ISO 8968-1:2014. Milk and milk products. Determination of nitrogen content. Part 1: Kjeldahl principle and crude protein calculation.

42. ISO 6731:2010. Milk, cream and evaporated milk. Determination of total solids content (Reference method).

43. Broido, A. A simple, sensitive graphical method of treating thermogravimetric analysis data. Journal of Polymer Science Part A-2: Polymer Physics 1969, 7, 1761-1773. https://doi.org/10.1002/pol.1969.160071012.

44. Claxton, L.D.; Umbuzeiro, G. De A.; David, M. The Salmonella mutagenicity assay: the stethoscope of genetic toxicology for the 21st century. Environmental Health Perspectives 2010, 118, 1515-1522, https://doi.org/10.1289/ehp.1002336.

45. Dudchik, N.V.; Filonov, V.P.; Kolyadich, E.S.; Melnikova, L.A.; Lilishentseva, A.N.; Ivaschenko, N.I. A method for determining the stimulating or inhibitory effect of a plant extract on the growth of a test strain of bacteria from the Enterobacteriaceae family. Patent Resp. Belarus, 2010, no. 15228. (In Russian).

46. Dudchik, N.V.; Melnikova, L.A. Impediometric method for determining the antimicrobial activity of dental materials. Hygiene and sanitation 2008, 1, 75-77. (In Russian).

47. Dudchik, N.V.; Shevlyakov, V.V. Prokaryotic test-models for the evaluation of biological action and hygienic regulation of environmental factors. Modern methodological problems of studying, assessing and regulating environmental factors that affect human health (Materials of the International Forum of the Scientific Council of the Russian Federation on Human Ecology and Environmental Hygiene); Moscow: Russia 2016, 1, 187-189. (In Russian).

48. Turbay, M.B.E.; De Moreno De Leblanc, A.; Perdigón, G.; Savoy De Giori, G.; Hebert, E.M. $\beta$-Casein hydrolysate generated by the cell envelope-associated proteinase of Lactobacillus delbrueckii ssp. lactis CRL 581 protects against trinitrobenzene sulfonic acid-induced colitis in mice. Journal of Dairy Science 2012, 95, 1108-1118. https://doi.org/10.3168/jds.2011-4735. 
49. Sah, B.N.P.; Vasiljevic, T.; Mckechnie, S.; Donkor, O.N. Effect of probiotics on antioxidant and antimutagenic activities of crude peptide extract from yogurt. Food Chemistry 2014, 156, 264-270, https://doi.org/10.1016/j.foodchem.2014.01.105.

50. Hati, S.; Das, S.; Mandal, S. Technological advancement of functional fermented dairy beverages. Engineering Tools in the Beverage Industry 2019, 3, 101-136, https://doi.org/10.1016/B978-0-12-8152584.00004-4.

51. Sah, B.N.P.; Vasiljevic, T.; McKechnie, S.; Donkor, O.N. Effect of refrigerated storage on probiotic viability and the production and stability of antimutagenic and antioxidant peptides in yogurt supplemented with pineapple peel. Journal of Dairy Science 2015, 98, 5905-5916, https://doi.org/10.3168/jds.2015-9450.

52. Halavach, T.N.; Tarun, E.I.; Dudchik, N.V.; Romanovich, R.V.; Yantsevich, A.I.; Asafov, V.A.; Khartitonov, V.D.; Kurchenko, V.P. Biological activities of fermented and hydrolysed bovine colostrum. News of Biomedical Sciences 2019, 19, 28-37. (In Russian).

53. Wada, Y.; Lönnerdal, B. Bioactive peptides derived from human milk proteins - mechanisms of action. The Journal of Nutritional Biochemistry 2014, 25, 503-514, https://doi.org/10.1016/j.jnutbio.2013.10.012.

54. Mohanty, D.P.; Mohapatra, S.; Misra, S; Sahu, P.S. Milk derived bioactive peptides and their impact on human health - a review. Saudi Journal of Biological Sciences 2016, 23, 577-583, https://doi.org/10.1016/j.sjbs.2015.06.005.

55. Mohanty, D.; Jena, R.; Choudhury, P.K.; Pattnaik, R.; Mohapatra, S.; Saini, M.R.Milk derived antimicrobial bioactive peptides: a review. International Journal of Food Properties 2016, 19, 837-846, https://doi.org/10.1080/10942912.2015.1048356.

56. Ben said Laila; Fliss, I.; Offret, C.; Beaulieu, L. Antimicrobial peptides: the new generation of food additives. Reference Module in Food Science, In: Encyclopedia of Food Chemistry. 2019, 576-582, https://doi.org/10.1016/B978-0-08-100596-5.21718-6. 